\title{
Relevansi Pendidikan Perspektif Harun Nasution (Religius-Rasional) Dengan Dunia Modern
}

\author{
Hambali Alman Nasution \\ Dosen UIN Sunan Kalijaga Yogyakarta \\ hambalialmannasution@gmail.com
}

Abstract: The purpose of this research is to find out how Harun Nasution's thinking in education and its relevance to the modern world. The research method used is a type oflibrary research (Library Research) with documentation data collection and data analysis using qualitative descriptive analysis with literature. Based on the research results, it is known that Harun Nasution is known to have expertise in the fields of rational and liberal theology and philosophy. Rational Islam is Islam which in explaining its teachings does not only rely on the opinion of revelation, but also includes reason. The implications of Harun Nasution's educational thought for the modern world are evident from the process of making IAIN Jakarta a center for the study of Islamic thought and moral education in all aspects of education that are more prioritized. And with a rational understanding of religion, we will be able to think rationally in addressing mankind's problems and their understanding.

Keywords: Education, Perspective, harun Nasution

Abstrak: Tujuan dari penelitian ini adalah untuk mengetahui bagaimana pemikiran Harun Nasution dalam pendidikan dan relevansinya dengan dunia modern. Metode penelitian 
menggunakan jenis penelitian kepustakaan (Library Research) dengan pengumpulan data dokumentasi dan analisis data menggunakan analisis deskriptif kualitatif dengan literatur. Berdasarkan hasil penelitian diketahui bahwa Harun Nasution dikenal memiliki keahlian dalam bidang teologi dan filsafat yang bercorak rasional dan liberal. Islam rasional adalah Islam yang dalam menjelaskan ajaran-ajarannya tidak hanya mengandalkan pendapat wahyu, tetapi juga mengikutsertakan akal pikiran. Implikasi pemikiran pendidikan Harun Nasution terhadap dunia modern yaitu terlihat dari proses menjadikan IAIN Jakarta sebagai pusat studi pemikiran Islam dan pendidikan moral di semua apsek pendidikan yang lebih diutamakan. Dan dengan pemahaman agama yang rasional maka akan dapat berfikir secara rasioanal dalam menyikapi masalah umat manusia dan pemahamanya.

Kata Kunci: Pendidikan, Perspektif, Harun Nasution.

\section{Pendahuluan}

Pendidikan merupakan suatu aktivitas untuk mengembangkan seluruh aspek kepribadian manusia yang berjalan seumur hidup. Pendidikan juga merupakan suatu kegiatan yang bermaksud membantu serta mempersiapkan generasi muda (masyarakat baru) dalam rangka menunaikan kompleksitas tugas dan kewajibannya di dalam hidup masyarakat. ${ }^{1}$ Sehingga mampu berdaya guna dalam masyarakat dan menjadi contoh teladan serta bertanggung jawab dengan apa yang ditugaskannya.

Sejalan dengan itu maka tujuan dari pendidikan di Indonesia ialah berkembangnya potensi peserta didik agar menjadi (1) manusia yang beriman dan bertaqwa kepada Tuhan Yang Maha Esa, (2) berakhlak mulia, (3) sehat, (4) berilmu, (5) cakap, (6) kreatif, (7) mandiri, dan (8)

1 Herlina Harahap, Pembaharuan Pendidikan Islam Perpektif Harun Nasution (Pontianak: STAIN Pontianak Press, 2006), 26 
menjadi warga negara yang demokratis dan bertanggung jawab. ${ }^{2}$ Selain pendidikan secara umum tujuan pendidikan dari segi Islam dijelaskan oleh salah satu pendapat tokoh Islam dalam buku Abd. Rahman Assegaf, al-Abrasyi berpendapat bahwa pembentukan moral yang tinggi adalah tujuan utama dari pendidikan Islam. Pendidikan budi pekerti adalah jiwa dari pendidikan Islam, karena Islam telah menyimpulkan bahwa pendidikan budi pekerti dan akhlak adalah jiwa dari pendidikan Islam. ${ }^{3}$ Dengan adanya tujuan pendidikan baik secara umum maupun tujuan pendidikan Islam, dapat dipahami bahwa tujuannya adalah untuk mengembangkan potensi peserta didik dan membentuk moral yang baik sehingga kelak berguna bagi masyarakat.

Untuk merealisasikan tujuan pendidikan tersebut tentunya ada beberapa pemikiran-pemikiran dari berbagai tokoh mengenai pentingnya pengembangan dan pembaharuan pendidikan di Indonesia. Salah satu tokoh intelekltual muslim adalah Harun Nasution, penggagas Islam rasional, tokoh sentral dalam menyampaikan ide pembaharuan dalam pendidikan Islam. Beliau memiliki kepribadian yang lembut, akan tetapi tegas dan konsisten dengan pemikirannya, mendalam isi pembicarannya serta membawa keteduhan dalam lingkungannya. Karena itu patut untuk dijadikan teladan oleh intelektual generasi berikutnya. Maka dari itu, di dalam makalah ini akan membahas mengenai biografi Harun Nasution, pemikiran pendidikannya dan implikasi pemikiran pendidikan di dunia modern.

\section{Metode Penelitian}

Adapun jenis penelitian yang digunakan penulis adalah penelitian pustaka (Library Research). Penelitian pustaka adalah penelitian yang dilaksanakan dengan menggunakan literatur (kepustakaan), baik berupa

2 Maragustam, Filsafat Pendidikan Islam Menuju Pembentukan Karakter (Yogyakarta: Pascasarjana, FITK UIN Sunan Kalijaga, 2019), 199.

3 Abd. Rahman Assegaf, Filsafat Pendidikan Islam; Paradigma Baru Pendidikan Hadhari Berbasis Intregatir-interkonektif, (Jakarta: PT. Raja Grafindo Parsada, 2014), 65-66. 
buku, catatan, maupun laporan hasil penelitian dari peneliti terdahulu. ${ }^{4}$ Adapun pendekatan yang digunakan dalam penelitian ini yaitu: Pendekatan paedagogik, pendekatan yang bersifat mendidik. Paedagogik diartikan dengan ilmu mendidik, lebih menitikberatkan kepada pemikiran, perenungan tentang pendidikan. Pedagogik merupakan suatu teori dan kajian yang secara teliti, kritis, dan obyektif mengembangkan konsep-konsepnya mengenai hakikat manusia, hakikat anak, hakikat tujuan pendidikan serta hakikat proses pendidikan. ${ }^{5}$ Sehingga pendekatan ini penting dalam penulisan makalah ini.

Kemudian dengan Pendekatan Historis, pendekatan historis yaitu suatu pendekatan yang digunakan untuk memahami berbagai peristiwa dengan memperhatikan unsur tempat, waktu, obyek, latar belakang, dan pelaku dari peristiwa tersebut dengan melihat kapan peristiwa itu terjadi, di mana, apa sebabnya, siapa yang terlibat dalam peristiwa tersebut. ${ }^{6}$ Dalam tulisan ini penulis menggunakan analisis deskriptif analitik, yaitu suatu pengambilan kesimpulan terhadap suatu objek, berbagai pemikiran, gambaran secara sistematis, faktual serta hubungannya dengan fenomena yang dianalisis. ${ }^{7}$

\section{Hasil dan Pembahasan}

\section{A. Sketsa Biografi Harun Nasution}

Harun Nasution lahir di Pematang Siantar, Sumatera Utara pada tanggal 23 September 1919. Beliau adalah putera keempat dari lima bersaudara yaitu yang pertama bernama M. Ayyub, kedua M. Khalil, ketiga Sa'idah, terakhir hafsah. ${ }^{8}$ Ayah Harun Nasution bernama Abdul Jabbar Ahmad Nasution adalah seorang ulama tradisional yang banyak

${ }^{4}$ Etta Mamang Sangadji dan Sopiah, Metodologi Penelitian: Pendekatan Praktis dalam Penelitian (Yogyakarta: Andi, 2010), 24.

5 Uyoh Sadulloh dkk, Pedagogik: Ilmu Mendidik (Bandung: Alfabeta, 2018), 2.

${ }_{6}^{6}$ Abudin Nata, Metodologi Studi Islam (Jakarta: Rajawali Pers, 2014), 46.

7 Maragustam, Filsafat Pendidikan Islam Menuju Pembentukan Karakter (Yogyakarta: Pascasarjana FITK UIN Sunan Kalijaga, 2018), 97.

8 Herlina Harahap, Pembaharuan Pendidikan Islam Perpektif Harun Nasution, 35. 
mempelajari ilmu fikih. Beliau mempelajari ilmu fikih dari ulama yang berada di daerahnya. Karena itu, ia mempunyai ilmu yang cukup untuk ukuran zaman itu, pada zaman kolonial yang tidak mudah mendapatkan akses pendidikan. ${ }^{9}$ Sedangkan ibunya bernama Maemunah Nasution juga berasal dari Mandailing yang bermarga Nasution. Ibunya berasal dari tanah Bato adalah keturunan ulama Mandailing, Tapanuli Selatan. Masa gadisnya pernah bermukim di Makkah dan pandai berbahasa Arab. Kedua orang tua Harun Nasution yang berpendidikan agama memberikan kontribusi dalam menanamkan pendidikan agamanya. Dengan latar belakang pendidikan yang dimiliki oleh orang tuanya sehingga seorang Harun Nasution dapat mengenyam pendidikan hingga menjadi seorang guru besar dan tokoh pembaharuan pendidikan Islam.

Setelah menyelesaikan pendidikan dasar, Hollandsch-Inlandshe School (HIS), kemudian melanjutkan studi Islam ke tingkat menengah yang bersemangat modernis, Moderne Islamietische Kweekschool (MIK). Karena desakan dari orang tuanya, ia meninggalkan MIK. ${ }^{10}$ Kemudian melanjutkan studinya ke Universitas al-Azhar di Kairo Mesir dan memperoleh Aliyah, pada tahun 1940 dan Kandidat dari Fakultas Ushuluddin pada tahun 1942. Di Mesir ia juga memasuki Universitas Amerika, Kairo dan memperoleh gelar Bachelor of Art (BA) dalam Studi Sosial pada tahun 1952. ${ }^{11}$ Dari Mesir, ia tertarik ke Jakarta, dan kemudian diberi pos sebagai sekretaris pada Kedutaan Besar Indonesia di Brussel. Setelah itu Nasution melanjutkan studinya di al-Dirasah al-Islamiyyah namun terhambat biaya, maka studinya tidak dapat dilanjutkan. Akhirnya ia menerima beasiswa dari Institute of Islamic Studies McGill di Montreal Kanada. Pada tahun 1965, Nasution memperoleh gelar Magister of Art (MA). Tiga tahun kemudian, tahun 1968, ia memperoleh gelar Doktor (Ph.D) dari almamater yang sama. ${ }^{12}$ Dari rentetan perjuangan pendidikan Harun Nasution mulai dari pendidikan di Indonesia hingga ke Kanada

\footnotetext{
9 Nurisman, Pemikiran Filsafat Islam Harun Nasution (Yogyakarta: Teras, 2014), 73.

${ }^{10}$ Budi Hadrianto, 50 Tokoh Islam Liberal Indonesia (Jakarta: Hujjah Press, 2007), 36.

${ }^{11}$ Herlina Harahap, Pembaharuan Pendidikan Islam Perpektif Harun Nasution, 36.

${ }^{12}$ Ibid.
} 
melahirkan seorang intelektual yang menjadi pembaharu pendidikan di Indonesia.

Dengan demikian Harun Nasution merupakan tokoh pembaharuan dalam pendidikan Islam yang mana memiliki gagasan dan pemikiran terhadap keterbelakangan pendidikan di Indonesia. (arifin) Dengan semangat juang yang dimiliki Harun Nasution sehingga dalam riwayat hidupnya menjadi seorang Guru Besar di IAIN Syarif Hidayatullah Jakarta dan memiliki karya-karya yang sangat luar biasa serta berguna bagi umat Islam dan bangsa Indonesia. Harun Nasution meninggal dunia pada tanggal 19 September 1998 dengan usia 79 tahun.

\section{B. Pemikiran Pendidikan Harun Nasution}

Harun Nasution dikenal sebagai seorang intelektual muslim yang banyak memperhatikan pembaharuan Islam dalam arti yang seluas-luasnya, tidak hanya terbatas pada bidang pemikiran saja seperti teologi, mistisisme (tasawuf) dan hukum (fiqih), akan tetapi juga mencakup seluruh aspek kehidupan kaum muslimin. Harun nasution berupaya agar masyarakat menggunakan akalnya sesuai dengan tuntunan Islam sebenarnya. ${ }^{13}$ Karena ide-idenya telah membawa perubahan besar dalam pemikiran Islam. ${ }^{14}$

Harun Nasution dikenal memiliki keahlian dalam bidang teologi dan filsafat yang bercorak rasional dan liberal. Islam rasional adalah Islam yang dalam menjelaskan ajaran-ajarannya tidak hanya mengandalkan pendapat wahyu, tetapi juga mengikutsertakan akal pikiran. Islam rasional juga berarti Islam yang menghargai pendapat akal pikiran dan menggunakannya untuk memperkuat dalil-dalil ajaran agama. Sehingga beliau juga menulis buku yang dimana judul bukunya adalah "Islam Rasional “ yang didalamnya membahas Islam yang rasional baik dari segi pembangunan umat, sosial-politik dan pengembangan ilmu pengetahuan

\footnotetext{
${ }^{13}$ Depi Yanti, “Konsep Akal dalam Perspektif Harun Nasution," Jurnal Intelektualita: Keislaman, Sosial dan Sains 6, no. 1 (5 Juli 2017): 51-62, https://doi.org/10.19109/ intelektualita.v6i1.1300.

${ }^{14}$ Khairunnas Jamal, "Pemikiran Tafsir Harun Nasution (Studi Tentang Pola Penafsiran Al-Qur'an Dalam Karya Tulis)," Jurnal Ushuluddin 18, no. 1 (1 Juni 2012): 58-69, https://doi.org/10.24014/jush.v18i1.699.
} 
dan pendidikan. Dengan pemahaman agama yang rasional maka akan dapat berfikir secara rasioanal dalam menyikapi masalah umat dan pemahamanya. ${ }^{15}$

Dengan corak pemikiran teologinya yang demikian itu, Harun Nasution dikenal pula sebagai ilmuan yang banyak mengemukakan gagasan dan pemikiran yang berbeda dengan pemikiran umumnya dianut umat Islam Indonesia. Di dalam pergulatan dengan berbagai faham aliran teologi tersebut serta hubungannya dengan kondisi sosial, ekonomi, budaya dan ilmu pengetahuan di Indonesian yang terbelakang, Nasution lebih kecenderungannya kepada teologi Mu'tazilah. Nasution melihat bahwa untuk mengatasi berbagai keterbelakangan umat Islam di Indonesia dalam berbagai bidang tersebut harus dilakukan dengan mengubah paham teologi yang dianutnya, yaitu dari paham teologi tradisional menjadi teologi yang rasional dan liberal. Dengan teologi Mu'tazilah Harun Nasution beranggapan dengan teologi itu mampu mengatasi keterbelakangan umat Islam di Indonesia diberbagai bidang.

Menurut Adian Husaini dalam buku Budi Hadrianto mengatakan bahwa sosok dan pemikiran Harun Nasution jarang dibahas dalam forum-forum publik. Padahal, dia punya andil besar dalam melakukan perombakan dan pembaharuan studi agama, terutama dalam bukunya, "Islam ditinjau dari berbagai aspeknya" yang digunakan sebagai salah satu referensi penting dalam mata kuliah studi Islam di berbagai IAIN. ${ }^{16}$ Bagaimana pun seorang Harun Nasution merupakan pembaharuan pendidikan Islam tentang studi agama di IAIN. Sebagai pembeharu pemikiran pendidikan Islam, pemikiran Harun Nasution yang berorientasi pada akal membawa umat Islam kepada ajaran yang sesuai Al-Qur'an dan Hadits, dan membuka kembali pintu ijtihad. ${ }^{17}$

${ }^{15}$ Muhammad Irfan, "Paradigma Islam Rasional Harun Nasution: Membumikan Teologi Kerukunan,” JURNAL ILMIAH SOSIOLOGI AGAMA (JISA) 1, no. 1 (30 Juni 2018): 109-27, https://doi.org/10.30829/jisa.v1i1.1784.

${ }^{16}$ Budi Hadrianto, 50 Tokoh Islam Liberal Indonesia.

${ }^{17}$ Muhammad Husnol Hidayat, "Harun Nasution dan Pembaharuan Pemikiran Pendidikan Islam," TADRIS: Jurnal Pendidikan Islam 10, no. 1 (2015): 23-38. 
Berdasarkan pengalaman belajar di Mesir dan Kanada, juga pengalaman berkarir di Mesir, Indonesia, Arab Saudi dan Belgia, Harun dengan cermat memetakan persoalan yang dihadapinya. Ada empat yang menjadi keprihatinan Harun Nasution, pertama perkembangan sikap dogmatisme dalam umat Islam. Umat Islam masih banyak terikat kepada arti harfiah teks. Gagasan pemikir muslim yang mencari makna metaforis teks, baik yang dilakukan oleh Mu'tazilah, filosof maupun sufi perlu dilakukan. Kedua, adanya anomali bahkan krisis dalam teologi tradisional Asy'ariah. Ahmad Wahib dalam buku hariannya itu juga merasakan anomali itu. Ia mengatakan bahwa teologi tradisional tidak relevan lagi dengan zaman sekarang. Ketiga, partisipasi dalam pembangunan yang sedang diagalakkan pemerintah pada masa Orde Baru. Dalam masa ini, persoalan keagamaan yang cukup penting adalah bagaimana mental umat Islam bisa menerima suasana pembangunan. Karena selama ini Islam di tanah air sangat kental dengan suasana politik dan ideologis. Keempat, dualisme pendidikan di tanah air, yaitu adanya pemisahan ilmu agama dan ilmu umum. Persoalan lebih serius digarap Harun setelah masa Tarmizi Taher menjadi Menteri Agama. ${ }^{18}$

Selain memetakan persoalan masalah Islam di Indonesia, Harun Nasution memiliki gagasan, pemikiran diantaranya adalah: pertama, umat Islam khususnya lingkungan IAIN harus berani mempertanyakan tradisi pemikiran Islam yang selama ini dianggap mapan dan mengadakan terobosan-terobosan liberal. Kedua, dalam Islam hanya sebagian kecil (5\%) ajaran-ajaran dasarnya yang bersifat mutlak. Sedangkan sisanya (95\%) merupakan ajaran yang bersifat relatif dan terbuka untuk dikaji dan ditelaah. Ketiga, ingin menjadikan Pascasarjana IAIN sebagai lembaga ilmiah. Keempat, umat Islam harus berani menguji dan mempertanyakan otoritas dan otentitas pemikiran-pemikiran sarjana (ulama) masa lampau. Kelima, akal adalah sumber utama untuk menggal ajaran-ajaran tertuang dalam al-Quran dam Hadits. Keenam, setiap orang berhak memiliki pendirian dan pemikirannya sendiri. Ketujuh, dalam mengkaji Islam kita harus berani mengatakan dan mengakui kesalahan, kelemahan serta kekurangan generasi Muslim sebelumnya supaya kita tidak terjebak

\footnotetext{
${ }^{18}$ Nurisman, Pemikiran Filsafat Islam Harun Nasution, 73.
} 
dengan kesalahan yang sama. Kedelapan, berkumpul dan berdiskusi dengan mahasiswa merupakan hiburan dan kepuasan intelektual yang tidak ternilai harganya. Kesembilan, berdasarkan pengalamannya, para sarjana Islam dari berbagai negara Muslim yang belajar ke barat selalu bersikap kritis terhadap pandangan-pandangan para orientalis. Kesepuluh, pandangan orientalis tentang Islam bersumber dari ketidak mengertian mereka pada Islam. Kesebelas, kebangkitan umat Islam tidak hanya ditandai dengan emosi keagamaan yang meluap-luap tetapi harus berdasarkan pemikiran yang dalam, menyeluruh dan filosofis terhadap agama Islam itu sendiri. ${ }^{19}$

Pemikiran pendidikan menurut Harun Nasution tidak sampai disitu saja. Di kutip dalam buku Herlina Harahap mengenai pemikiran pendidikan Islam Harun Nasution yaitu sebagai berikut:

1. Dikotomi Pendidikan

Kata dikotomi berasal ari bahasa inggris "dichotomy" yang artinya membedakan dan mempertentangkan dua hal yang berbeda. Secara terminologis, praktiknya mengatakan bahwa dikotomi dipahami sebagai pemisahan antara ilmu dan agama yang kemudian berkembang menjadi fenomena dikotomik-dikotomik lainnya, seperti dikotomi ulama dan intelektual, dikotomi dalam dunia pendidikan Islam dan bahkan dikotomi dalam diri muslim itu sendiri. Sedangkan menurut Harun Nasution mengistilahkan dikotomi pendidikan dengan istilah "dualisme pendidikan". Maksud dari istilah tersebut adalah menciptakan dua kelompok kaum intelektual yakni intelektual di bidang agama dan intelektual di bidang sains dimana di antara keduanya terdapat kesenjangan hubungan. Dikotomi terjadi karena adanya perbedaan sehingga mengakibatkan perdebatan kedua hal tersebut baik dibidang pendidikan maupun dibidang lainnya sehingga perlunya pemerataan pendidikan yang mampu mendamaikan kedua hal tersebut. ${ }^{20}$

\footnotetext{
${ }^{19}$ Herlina Harahap, Pembaharuan Pendidikan Islam Perpektif Harun Nasution, 68.

${ }^{20}$ Herlina Harahap, Pembaharuan Pendidikan Islam Perpektif Harun Nasution, 93.
} 
Menurut Harun Nasution dalam buku Nurisman, salah satu persoalan mendasar yang menyangkut masalah pendidikan yaitu terjadinya dualisme dalam pendidikan, yakni pemisahan pendidikan qalbiyah dan aqliyah. Pada masa kemajuan Islam, kedua ranah ini diintegrasikan dengan baik. Namun, setelah masa kemunduran Islam dan selanjutnya dunia Islam, mulai banyak mendapat pengaruh dari barat sehingga terjadi pemisahan. ${ }^{21}$

Di Indonesia dari zaman penjajahan mulai terjadi dikotomi pendidikan, pada zaman penjajahan dikotomi pendidikan itu terlihat dengan adanya perbedaan pendidikan antara kaum penjajah dan kaum pribumi. Orang-orang belanda memerlukan pendidikan dan latihan mengenai Indonesia agar mereka mampu mengusai Indonesia dan menjadikan pribumi sebagai pembantu pada saat itu sehingga dikotomi pendidikan sangat jelas pada saat itu. Setelah zaman penjajahan pada masa orde lama masih terjadi dikotomi pendidikan antara pendidikan agama dengan pendidikan umum sehingga terjadi pertentangan dan perdebatan pada saat itu.

Penyebab terjadinya dikotomi pendidikan di Indonesia tidak lain karena sistem pendidikan modern menyatakan subjek-subjek keagamaan hendaknya diajarkan dengan cara sama seperti subjeksubjek non agama sistem ini menerima dukungan penuh dari pemerintah. Sedangkan sistem pendidikan tradisional lebih senang berkutat pada pengajaran ilmu-ilmu keagamaan. Tentu saja mereka mengabaikan perkembangan yang datang dari barat. Oleh karena itu, wajar saja bila penganut sistem ini ketinggalan zaman. Sehingga fenomena ini banyak melanda di negara-negara muslim seperti Indonesia.

Solusinya menurut Fazlur Rahman dalam buku Herlina Harahap, salah satu pendekatannya adalah dengan menerima pendidikan sekuler modern sebagaimana telah berkembang secara umum didunia barat dan mencoba mengislamkannya yakni mengisinya dengan konsepkonsep kunci tertentu dari Islam. ${ }^{22}$ Dengan mengubah konsep-konsep

${ }^{21}$ Nurisman, Pemikiran Filsafat Islam Harun Nasution.

${ }^{22}$ Herlina Harahap, Pembaharuan Pendidikan Islam Perpektif Harun Nasution, 101. 
barat menjadi konsep Islam maka akan terjadi perkembangan ilmu pengetahuan di dunia Islam sehingga Islam tidak ketinggalan dari zaman modern.

Menurut Harun Nasution dalam buku Herlina Harahap sains tidak terlepas dengan agama. Karena, sains berhadapan dan bersamaan dengan agama. Jadi, agama dalam konteks ini harus memiliki pengertian sebenarnya, yakni Islam sebenarnya adalah Islam yang hanya menginformasikan fiqih, tauhid, tafsir, hadits dan bahasa arab, tetapi melebar pada sejarah, filsafat, peradaban, tasawuf, bahkan pranata-pranata sosial dan hukum. Lebih dari itu, Islam tidak sematamata sebagai sistem agama saja, tetapi juga meliputi seluruh aspek kehidupan manusia baik spritual, fisik maupun intelektual. Jadi sudah jelas Islam itu bukan hanya sekedar mengajarkan aqidah saja tetapi lebih jauh menjelaskan tentang kehidupan didunia ini.

2. Hubungan Antar Agama dan Moral

Hubungan agama dan moral itu sangat erat serta merupakan hal yang sangat esensial. Sebagaimana dalam Islam tepatnya di dalam al-Quran banyak terdapat ajaran-ajaran mengenai akhlak, tingkah laku dan etika. Dengan adanya ajaran-ajaran tersebut sehingga umat Islam akan mempelajari dan melaksanakan dikehidupan sehari-hari.

Tujuan dari pendidikan moral tersebut menurut Harun Nasution dalam buku Herlina Harahap adalah membentuk manusia yang berbudi luhur. Jadi, tujuan pendidikan agama seharusnya bukanlah pengajaran pengetahuan agama dan pratik-praktik ibadah sematamata, tetapi hal yang terpenting di samping itu adalah pendidikan moral. Dalam pendidikan agama, terutama di TK, SD, SMP dan SMA, pendidikan moral inilah rasanya sangat perlu diutamakan. Pelajaranpelajaran mengenai keagamaan lain, terutama ibadah sebaiknya dihubungkan dengan pendidikan moral ini. Di Perguruan Tinggi (PT), pendidikan moral masih dapat dilanjutkan, tetapi di sini yang perlu ditekankan adalah pendidikan spritual dan pelajaran rasional tentang ajaran agama. ${ }^{23}$

\footnotetext{
${ }^{23}$ Ibid, 110.
} 
Melihat fenomena moral yang menjadi permasalahan pendidikan di Indoensia, maka Harun Nasution berpendapat dalam buku Nurisman bahwa pendidikan yang serba intelektual dan ditambah pelaksanaan ibadah yang formalitas, tidak mampu membina hidup kerohanian dan moral umat. Padahal yang diperlukan dunia sekarang ini dalam rangka membendung materialisme adalah hidup kerohanian dan moral agama. Harun Nasution melihat pendidikan dan pelaksanaan ibadah itu hanya formalitas kenapa tidak hal ini terjadi karena materialisme sudah menjalar ke tokoh-tokoh agama sehingga moral dan akhlaknya hilang ditelan zaman. Maka dari itu, perlunya pendidikan moral mulai dari tingkat TK hingga ke perguruan tinggi sehingga menjadi dasar penghalang untuk masuknya fahamfaham radikal yang dapat merusak bangsa Indonesia secara umumnya dan invidu secara khususnya. ${ }^{24}$

3. Metode

Menurut Harun Nasution dalam buku Herlina Harahap tujuan utama pendidikan agama adalah pendidika moral, maka metode yang sebaiknya dipakai antara lain ialah: (a) pemberian contoh dan teladan yang baik dari pendidik agama kepada anak didik; (b) pemberian nasihat kepada siswa atau mahasiswa; (c) tuntunan dalam menyelesaikan persoalan moral; (d) kerja sama dengan lingkungan rumah dan lingkungan pergaulan anak didik; (e) kerja sama dengan pendidik pengetahuan umum lainnya; dan (f) metode tanya jawab dan diskusi dalam hal pendekatan intelektual tentang ajaran-ajaran agama Metode yang diberikan oleh Harun Nasution tujuannya adalah untuk memperbaiki dan mengembangkan pendidikan Islam itu sendiri terkhusus kepada pendidikan moral peserta didik. ${ }^{25}$

4. Kualitas Pendidik Agama

Untuk mencapai pendidik yang berkualitas dan mampu menjadi contoh teladan bagi peserta didik maka dari itu Harun Nasution berpendapat dalam buku Herlina Harahap mengenai syarat-syarat

\footnotetext{
${ }^{24}$ Nurisman, Pemikiran Filsafat Islam Harun Nasution, 68.

${ }^{25}$ Herlina Harahap, Pembaharuan Pendidikan Islam Perpektif Harun Nasution, 112.
} 
yang perlu bagi pendidik agama antara lain: (a) sanggup memberi contoh teladan yang baik bagi anak didik; (b) mengusai ilmu-ilmu yang erat hubungannya dengan pendidikan anak; (c) mempunyai pengetahuan yang luas tentang agama; (d) mempunyai pengetahuan umum yang seimbang dengan pengetahuan yang dipelajari oleh siswa dan mahasiswa. Dengan syarat-syarat itu maka akan tercipta suasana pendidikan yang berkualitas dan menghasilkan peserta didik yang berkualitas pula.

5. Bahan Pendidikan Agama

Bahan pendidikan agama atau biasa dikatakan sebagai mata pelajaran sebaiknya berkaitan langsung dengan tujuan pendidikan moral. Menurut Harun Nasution dalam buku Herlina Harahap di dalam pendidikan Islam maka bahan pendidikan agama tidak pernah lepas dari bagian-bagian ilmu fiqh, sejarah, akidah dan al-Quran hadits. Dibawah ini akan dipaparkan pandangan Harun Nasution tentang ilmu-ilmu tersebut: ${ }^{26}$

Pertama, Fiqh, Fiqh atau hukum Islam merupakan salah satu bidang pendidikan studi Islam yang paling dikenal oleh masyarakat. Hal ini antara lain karena fiqh terkait langsung dengan kehidupan masyarakat dari sejak lahir sampai meninggal dunia manusia selalu berhubungan dengan fiqh. Menurut Harun Nasution dalam bukunya akal dan wahyu dalam Islam, bahwa kata fahiqa mengandung makna fakar dan mengerti memahami dan mengerti sesuatu masalah diperlukan pemikiran dan pemakaian akal. Dalam suatu pemahaman dan penafsiran diperlukan Al-ijtihad. Ijtihad mengandung makna usaha keras dalam hukum mempunyai arti usaha keras dalam bentuk pemikiran akal untuk mengeluarkan ketentuan hukum agama dari sumber-sumbernya. Fiqh merupakan mata pelajaran yang sangat penting guna untuk memahami cara-cara beribadah kepada Allah swt. dan memahami dasar ibadah tersebut.

Kedua, Sejarah. Sejarah Islam merupakan salah satu bidang studi Islam yang banyak menarik perhatian para peneliti dikalangan

\footnotetext{
${ }^{26} \mathrm{Ibid}, 113$.
} 
sarjana Muslim maupun non-muslim. Bagi umat Islam, mempelajari sejarah Islam selain memberikan kebanggan juga sekaligus peringatan agar hati-hati.dengan mengetahui sejarah kita mampu memahami kemajuan apa yang diperoleh begitu pun mengetahui mengenai kemunduran Islam, penjajahan dan lain sebagainya.

Ketiga, Akidah. Akidah Islam merupakan penutup akidah bagi agama-agama yang pernah diturunkan oleh Allah sebelumnya, bersamaan diutusnya nabi Muhammad saw. sebagai Rasul Allahyang terakhir. Akidah merupakan hakikat abadi yang tidak akan pernah mengalami proses perubahan hingga akhir masa. Akidah merupakan poin penting dalam mata pelajaran membahas mengenai keyakinan kita, baik keyakinan kepada Allah swt. begitupun dengan malaikat, nabi, rasul , kitab serta hari kiamat serta qada dan qadar. Akidah juga dikatakan sebagai dasar kita beragama dengan akidah yang benar maka mengantarkan kita kejalan yang benar pula.

Keempat, al-Quran dan Hadits. Dasar yang terpenting bagi pengetahuan agama ialah wahyu. Wahyu ialah kebenaran yang langsung disampaikan Tuhan kepada salah seorang dari hambanya. Dengan kata lain wahyu terjadi karena adanya komunikasi antara Tuhan dan manusia. Al-Quran sebagai kitab suci yang mengandung sabda Tuhan (Kalam Allah), yang melalui wahyu yang disampaikan kepada nabi Muhammad saw. Al-Quran hadits merupakan mata pelajaran wajib bagi pendidikan agama karena Al-Quran hadits merupakan sumber ilmu pengetahuan bukan saja ilmu agama tetapi semua.

Setelah pemikiran Harun Nasution telah tersebar dan dipelajari oleh banyak orang sehingga memicu adanya pertentangan akan pemikiran tersebut. Meskipun terjadi pertentangan tentang pemikiran Harun Nasution tetapi pemikiran Harun Nasution juga memiliki dampak atau implikasi di dunia modern yaitu mind set IAIN dan Pendidikan Moral.

IAIN sebagai lembaga pendidikan tinggi Islam dulunya adalah perguruan tinggi yang pemikiran tradisional dan mengacu pada metode Al-Azhar dengan titik berat penekanan pada mashab Syafi'i 
sehingga lulusan IAIN memiliki pemikiran yang sempit. Dalam pemikirannya Harun Nasution mengatakan khususnya di lingkungan IAIN, harus berani mempertanyakan tradisi pemikiran Islam yang selama ini dianggap mapan dan mengadakan terobosan-terobosan liberal. Kemudian ingin menjadikan Pascasarjana IAIN sebagai lembaga ilmiah yang menampung berbagai pemikiran, meskipun bertentangan, sehingga berkembang menjadi dinamika yang sangat berguna bagi penambahan wawasan mahasiswanya. Dan akhirnya hal itu direalisasikan ketika Harun Nasution menjadi Rektor IAIN Syarif Hidayatullah pada saat itu serta menata IAIN menjadi kampus pembaharuan pemikiran di Indonesia.

Pendidikan moral yang diutarakan oleh Harun Nasution sebagai tujuan utama dari pendidikan adalah membentuk manusia yang berbudi luhur. Jadi, tujuan pendidikan agama seharusnya bukanlah pengajaran pengetahuan agama dan pratik-praktik ibadah sematamata, tetapi hal yang terpenting di samping itu adalah pendidikan moral. Maka dari itu pendidikan moral sangat dikedepankan sebagai dasar peserta didik dalam menempuh pendidikan untuk menunjang tujuan pendidikan. Menurut Harun Nasution metode dan bahan ajar dalam pendidikan tidak terlepas dari pendidikan moral. Metode yang digunakan mencakup seperti pemberian contoh teladan dari pendidik, memberikan nasihat, kerja sama dengan lingkungan peserta didik. Sedangkan bahan ajar digunakan tentunya tujuannya untuk menjadikan peserta didik yang memiliki moral yang baik maka bahan ajar yang digunakan adalah ilmu fiqh, sejarah, akidah dan alQuran Hadits.

\section{Penutup}

Implikasi pemikiran pendidikan Harun Nasution terhadap dunia modern yaitu terlihat dari proses menjadikan Pascasarjana IAIN sebagai lembaga ilmiah yang menampung berbagai pemikiran, meskipun bertentangan, sehingga berkembang menjadi dinamika yang sangat berguna bagi penambahan wawasan mahasiswanya. Kemudian pendidikan moral yang diutarakan oleh Harun Nasution sebagai tujuan utama dari 
pendidikan adalah membentuk manusia yang berbudi luhur, sehingga di aplikasikan dalam metode pembelajaran, bahan pelajaran agama dan sebagainya. Harun Nasution dikenal memiliki keahlian dalam bidang teologi dan filsafat yang bercorak rasional dan liberal yang menghargai pendapat akal pikiran dan menggunakannya untuk memperkuat dalildalil ajaran agama.juga memiliki pemikiran di bidang pendidikan yakni mengenai dikotomi pendidikan, hubungan agama dan moral, metode, kualitas pendidikan agama dan bahan pendidikan agama.

\section{Daitar Pustaka}

Assegaf, Abd. Rahman. Filsafat Pendidikan Islam; Paradigma Baru Pendidikan Hadhari Berbasis Intregatir-interkonektif,. Jakarta: PT. Raja Grafindo Parsada, 2014.

Nata, Abudin. Metodologi Studi Islam, Jakarta: Rajawali Pers, 2014.

Hadrianto, Budi. 50 Tokoh Islam Liberal Indonesia. Jakarta: Hujjah Press, 2007.

Sangadji, Etta Mamang dan Sopiah. Metodologi Penelitian: Pendekatan Praktis dalam Penelitian. Yogyakarta: Andi, 2010.

Harahap, Herlina. Pembaharuan Pendidikan Islam Perpektif Harun Nasution. Pontianak: STAIN Pontianak Press, 2006.

Hidayat, Muhammad Husnol. "Harun Nasution dan Pembaharuan Pemikiran Pendidikan Islam." TADRIS: Jurnal Pendidikan Islam 10, no. 1 (2015): 23-38.

Irfan, Muhammad. "Paradigma Islam Rasional Harun Nasution: Membumikan Teologi Kerukunan." JURNAL ILMIAH SOSIOLOGI AGAMA (JISA) 1, no. 1 (30 Juni 2018): 109-27. https://doi. org/10.30829/jisa.v1i1.1784.

Jamal, Khairunnas. "Pemikiran Tafsir Harun Nasution (Studi Tentang Pola Penafsiran Al-Qur’an Dalam Karya Tulis)." Jurnal Ushuluddin 18, no. 1 (1 Juni 2012): 58-69. https://doi.org/10.24014/jush.v18i1.699. 
Maragustam. Filsafat Pendidikan Islam Menuju Pembentukan Karakter. Yogyakarta: Pascasarjana FITK UIN Sunan Kalijaga, 2018.

-_- Filsafat Pendidikan Islam Menuju Pembentukan Karakter. Yogyakarta: Pascasarjana, FITK UIN Sunan Kalijaga, 2019.

Nurisman. Pemikiran Filsafat Islam Harun Nasution. Yogyakarta: Teras, 2014.

Sadulloh, Uyoh., dkk. Pedagogik: Ilmu Mendidik. Bandung: Alfabeta, 2018. Yanti, Depi. "Konsep Akal dalam Perspektif Harun Nasution." Jurnal Intelektualita: Keislaman, Sosial dan Sains 6, no. 1 (5 Juli 2017): 51-62. https://doi.org/10.19109/intelektualita.v6i1.1300. 
